\title{
Sensitivity of the Pyrenophora teres Population in Algeria to Quinone outside Inhibitors, Succinate Dehydrogenase Inhibitors and Demethylation Inhibitors
}

\author{
Hamama-Imène Lammari $\mathbb{D i}^{1 *}$, Alexandra Rehfus ${ }^{2}$, Gerd Stammler ${ }^{2}$, and Hamida Benslimane ${ }^{3}$ \\ ${ }^{I}$ Phytopathology and Molecular Biology Laboratory, Department of Botany, National High College of Agriculture, \\ Algiers, Algeria \\ ${ }^{2}$ BASF SE, Agricultural Centre, 67117 Limburgerhof, Germany \\ ${ }^{3}$ Integrative Improvement of Crop Production Laboratory (Amélioration Intégrative des Productions Végétales), Depart- \\ ment of Botany, National High College of Agriculture, Algiers C2711100, Algeria
}

(Received on September 15, 2019; Revised on March 25, 2020; Accepted on April 21, 2020)

Net blotch of barley caused by Pyrenophora teres (Died.) Drechsler, is one of the most destructive diseases on barley in Algeria. It occurs in two forms: $P$. teres f. teres and $P$. teres $f$. maculata. A total of 212 isolates, obtained from 58 fields sampled in several barley growing areas, were assessed for fungicide sensitivity by target gene analysis. F129L and G137R mitochondrial cytochrome $b$ substitution associated with quinone outside inhibitors (QoIs) resistance, and succinate dehydrogenase inhibitors (SDHIs) related mutations (B-H277, C-N75S, C-G79R, C-H134R, and C-S135R), were analyzed by pyrosequencing. In vitro sensitivity of 45 isolates, towards six fungicides belonging to three chemical groups (QoI, demethylase inhibitor, and SDHI) was tested by microtiter technique. Additionally, sensitivity towards three fungicides (azoxystrobin, fluxapyroxad, and epoxiconazole) was assessed in planta under glasshouse conditions. All tested isolates were QoI-sensitive and SDHI-sensitive, no mutation that confers resistance was identified. $\mathrm{EC}_{50}$ values showed that pyraclostrobin and azoxystrobin are the most efficient fungicides in vitro, whereas fluxapyroxad displayed the best disease inhibi-

\footnotetext{
*Corresponding author.

Phone) +213(0)-550-319034

E-mail)h.lammari@st.ensa.dz

ORCID

Hamama-Imène Lammari

https://orcid.org/0000-0002-0170-6967

(c) This is an Open Access article distributed under the terms of the Creative Commons Attribution Non-Commercial License (http:// creativecommons.org/licenses/by-nc/4.0) which permits unrestricted noncommercial use, distribution, and reproduction in any medium, provided the original work is properly cited.
}

Articles can be freely viewed online at www.ppjonline.org. tion in planta ( $81 \%$ inhibition at $1 / 9$ of the full dose). The $\mathrm{EC}_{50}$ values recorded for each form of net blotch showed no significant difference in efficiency of QoI treatments and propiconazole on each form. However, in the case of fluxapyroxad, epoxiconazole and tebuconazole treatments, analysis showed significant differences in their efficiency. To our knowledge, this study is the first investigation related to mutations associated to QoI and SDHI fungicide resistance in Algerian $P$. teres population, as well as it is the first evaluation of the sensitivity of $P$. teres population towards these six fungicides.

Keywords : demethylase inhibitors, Pyrenophora teres, quinone outside inhibitors, sensitivity, succinate dehydrogenase inhibitors

Handling Editor : Junhyun Jeon

Net blotch is one of the most common diseases of barley worldwide and it occurs in all barley growing regions (Weibull et al., 2003). The causal agent is the heterothallic, ascomycete fungus Pyrenophora teres (Died.) Drechsler (asexual morph: Drechslera teres (Sacc.) Shoem.). It occurs in two forms, P.teres f. teres (Ptt) and P.teres $\mathrm{f}$. maculata (Ptm). In Algeria, where net blotch is widespread (Benbelkacem et al., 2002; Srivastrava and Tewari, 2002), barley (Hordeum vulgare L.) is one of the most important cereals. Barley is used in human nutrition for traditional dishes (Hales, 2015; Rahal-Bouziane, 2015) and serves as sheep, cattle and camels feed. The consumption has increased since 2000 due to the rise of livestock numbers in Algeria (Hales, 2015; Rahal-Bouziane, 2015). For these 
needs, Algeria produced 1,957,327 tons in 2018, with a cultivated area of 1,277,512 ha (Food and Agriculture Organization of the United Nations, 2020).

However, the production level remains low compared with the market needs; therefore Algeria imported 289,644 tons of barley in 2018 (Observatoire National des filières Agricoles et Agroalimentaires, 2019). Among many biotic antagonists with which barley cultivation is faced (Benbelkacem, 1996), net blotch can cause an average loss up to $40 \%$ (Sayoud et al., 1999). Only two barley landraces, Saida183 and Tichedrette, are relevant in Algeria (GhalemDjender et al., 2016) and they are both highly susceptible to net blotch (Reguieg et al., 2013).

In addition to disease-resistant varieties and agricultural practices, fungicides are used to support the control of $P$. teres worldwide. With the lack of highly resistant cultivars, net blotch diseases are mostly controlled by fungicides application (Sierotzki et al., 2007). Many fungicides classes are used in the control of net blotch worldwide and these include: quinone outside inhibitors (QoIs), succinate dehydrogenase inhibitors (SDHIs), and demethylase inhibitors (DMIs) (Mair et al., 2016a; Rehfus et al., 2016; Stepanović et al., 2016).

Different QoIs show excellent control of net blotch and are registered in most important barley growing regions (Semar et al., 2007). This fungicide group inhibits mitochondrial respiration of the fungus by binding to the Qo site of the cytochrome $b c l$ complex, the electron transfer is then blocked and ATP synthesis is halted (Fernández-Ortuño et al., 2008). Consequently, an inhibition of spore germination and mycelia development is induced (Reddy, 2013). SDHI fungicides are also currently used in the control of P. teres, especially in Europe (Rehfus et al., 2016). Their target site is the succinate dehydrogenase (SDH) enzyme, fungal respiration is inhibited by blocking the ubiquinonebinding sites in the mitochondrial complex II (Avenot and Michailides, 2010). DMIs are still used worldwide and are also important fungicides in Algeria (Direction de la Protection des Végétaux et des Contrôles Techniques, 2017). The enzyme cytochrome P450 sterol $14 \alpha$-demethylase is the specific target site of DMIs, thus, they inhibit sterol $14 \alpha$-demethylation by binding selectively to CYP51 and, in consequence, DMIs block the biosynthesis of fungal ergosterol, which is the major component of fungal membranes (Lamb et al., 1991; López-Ruiz et al., 2010).

Despite the excellent efficacy of fungicides in plant disease control, after many years of application, many pathogens have succeeded to develop fungicide resistance (Avenot and Michailides, 2010; Fernández-Ortuño et al., 2008; Mair et al., 2016a). Hence, the rise of pathogens' lineage that show resistance or reduced sensitivity has affected the performance of numerous modern fungicides (Marzani et al., 2013).

Three target site mutations in cytochrome $b$ (F129L, G137R, and G143A) have been detected in plant pathogenic fungi that are responsible for QoI resistance (Fisher and Meunier, 2008; Fungicide Resistance Action Committee, 2019). Two of them, F129L (substitution of phenylalanine by leucine at 129 position) and very rarely G137R (substitution of glycine by arginine at 137 position) have been found in $P$. teres population (Fungicide Resistance Action Committee, 2019; Marzani et al., 2013). The emergence of resistance to SDHI fungicides in this fungus was found to be associated with numerous mutations that occur in the genes coding for SDH enzyme subunits. In Europe, genetic analyses have highlighted one mutation in $s d h$ $B$ (B-H277Y), 4 mutations in $s d h-C$ (C-N75S, C-G79R, C-H134R, C-S135R), and 4 in $s d h-D$ (D-D124N/E, DH134R, D-D145G, D-E178K), and that mutations in $s d h$ $C$ genes have been found to be the most frequent (Rehfus et al., 2016). The main mechanisms that cause lower DMI sensitivity are amino acid changes in the molecular target of azoles (CYP51) and overexpression of CYP51 (Mair et al., 2016a). Thus, $P$. teres f. teres strains with lower DMI carry Cyp51A:KO103A1, an allele with the mutation F489L in Cyp51A gene (Mair et al., 2016a).

Fungicides efficiency analyses and resistance monitoring are very important in disease control strategies. In Australia, a failure in barley powdery mildew control using DMIs led to an economic damage estimated to be $\mathrm{AU}$ $\$ 100 \mathrm{~m}$ annually. This is the most damaging epidemic in history caused by fungicide resistance (Tucker et al., 2015). Although QoI, SDHI, and DMI resistances in P. teres are currently extensively spread in several countries (Mair et al., 2016a; Marzani et al., 2013; Rehfus et al., 2016; Semar et al., 2007; Sierotzki et al., 2007), no investigations have been made with respect to the status of these resistances in Algeria and in North African geographical areas.

Hence, our interest should be focused on the fungicide sensitivity status in this area because the epidemiology of this fungus shows sexual and asexual reproduction. This could lead to a higher possibility of evolution, and to an increased risk of the emergence of fungicide resistance (McDonald and Linde, 2002). This is also likely in Algeria, where a high pathogenic variability has been reported in the population of $P$. teres f. teres (Boungab et al., 2012).

In fact, pathogen populations with large genetic variation can rapidly respond to changing environments and overcome fungicide treatments (Peltonen et al., 1996). Furthermore, during the growing season, several secondary cycles 
of $P$. teres can occur through conidia production (Liu et al., 2011); hence, this fungus is in haploid state for the major part of his life. Haploidy and a high genetic adaptability of fungi are factors that are associated with a higher risk for fungicide resistance emergence and spread within a population (Angelini et al., 2015; Brent and Hollomon, 2007).

Several DMI and QoI fungicides are commercialized in Algeria for the control of net blotch (Direction de la Protection des Végétaux et des Contrôles Techniques, 2017). However, the lack of data about the sensitivity of the Algerian population of $P$. teres to SDHI fungicides, hampers the setup of efficient chemical control programmes that include this important group of fungicides. An effective chemical control for this disease in Algeria would be very helpful; it would the barley yield to increase and thus to decrease the need for its importation. This study was conducted in order to investigate the actual status of fungicide sensitivity in Algeria against the three fungicides groups (QoI, SDHI, and DMI). Its main objective was to assess their efficiencies against Algerian population of $P$. teres. To this purpose, the presence of mutations that lead to QoI and SDHI resistance were first investigated. Then, the efficacies of six fungicides from the QoI, SDHI, and DMI groups, were compared in vitro in microtiter plates, and in planta under controlled conditions.

\section{Materials and Methods}

Fungal isolates. A total of 58 barley fields were moni- tored at 42 distinct locations in 17 Algerian provinces. The survey was conducted in the western, central and eastern regions in the northern part of Algeria (Fig. 1, Supplementary Table 1). After surface leaf sterilization in 3\% sodium hypochlorite solution for $5 \mathrm{~min}$, barley leaf sections with net blotch symptoms were rinsed three times in sterilized distilled water, and then incubated in a moisture chamber. After a 3-day incubation period at $22^{\circ} \mathrm{C}$ under $12 \mathrm{~h}$ photoperiod, single conidia of $P$. teres were picked from the lesions with a stretched sterile Pasteur pipette under a binocular magnifying glass $(\mathrm{G} \times 40)$ and transferred to potato dextrose agar plates. A total of 212 monospore isolates (165 $P$. teres f. teres and 47 P. teres f. maculata) were obtained and used in this work (Lammari et al., 2020).

Nucleic acid extraction. For DNA extraction, approximately $100 \mathrm{mg}$ of fresh fungal tissue (of each isolate) were scraped from pure fungal colonies and ground to a fine powder, using sterilized steel beads and thoroughly homogenized in a Tissue Lyser (Qiagen, Hilden, Germany). DNA extraction of the 212 isolates was conducted using Nucleo-Spin DNA Plant II kit, with the vacuum processing (Macherey-Nagel, Düren, Germany), according to instructions of the manufacturer.

Detection of QoI and SDHI resistance by pyrosequencing. Pyrosquencing assays were performed according to Rehfus (2018) in order to detect mutations in cytochrome $b$ (F129L mutation) and in the SDH enzyme (different

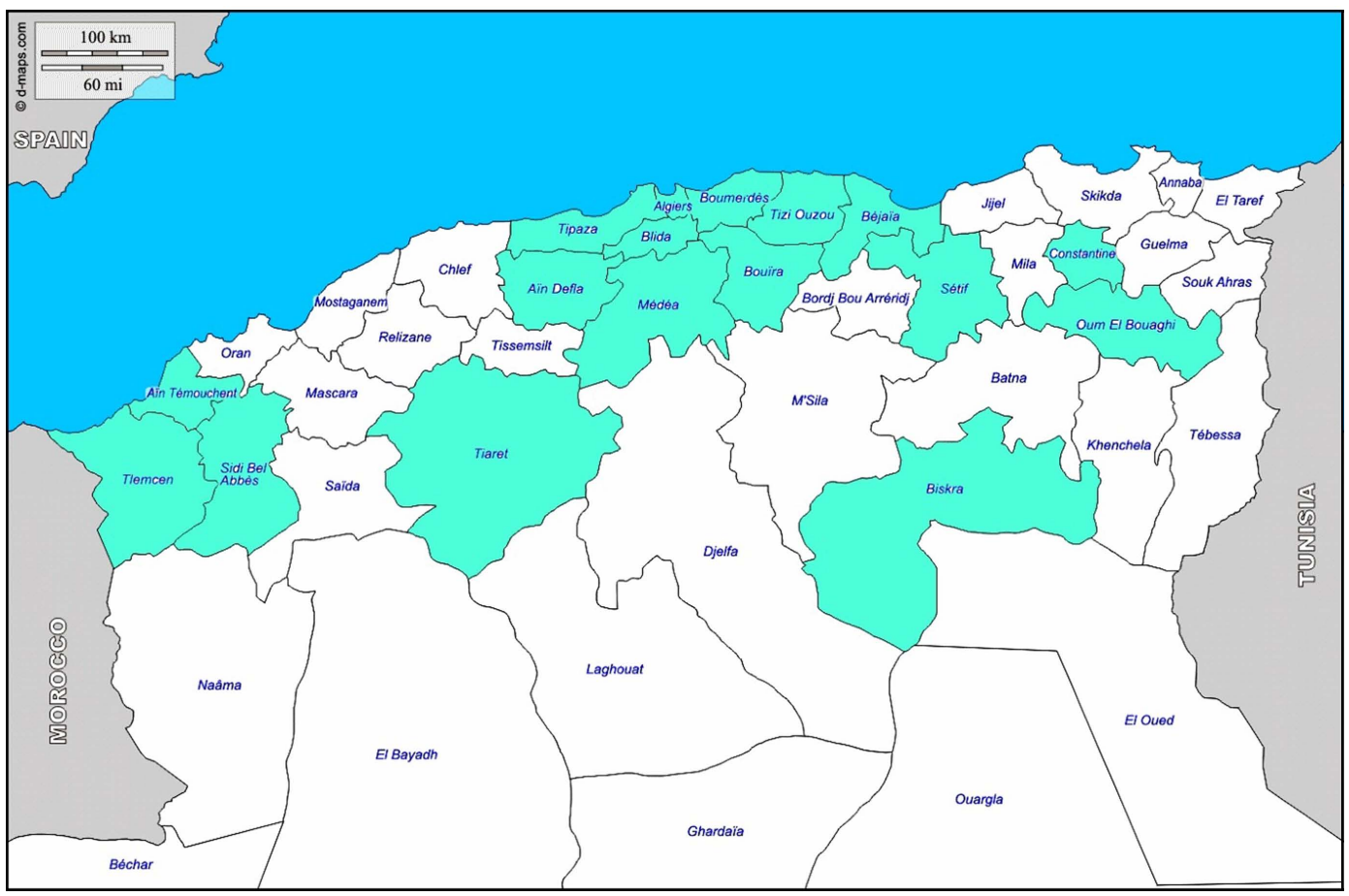

Fig. 1. Map of Algeria, showing sampled areas, where barley is growing. 
mutations in $s d h-B$ and $s d h-C$ subunits). PCR reactions were made in a final volume of $25 \mu$ l. This contained 12.5 $\mu 1$ Maxima Hot Start PCR Master Mix (2×) (Fermentas $\mathrm{GmbH}$, St. Leon-Rot, Germany), $1.25 \mu \mathrm{l}(10 \mathrm{pmol} / \mu \mathrm{l})$ of primer pairs where one primer was a biotinylated oligonucleotide (biomers) (Supplementary Table 2), $7.5 \mu 1$ of distilled water and $2.5 \mu \mathrm{l}(1-30 \mu \mathrm{g})$ of template DNA. The Maxima Hot Start PCR Master Mix included Maxima Hot Start Taq DNA polymerase, $2 \times$ hot start PCR buffer, 0.4 $\mathrm{mM}$ of each dNTP, and $4 \mathrm{mM} \mathrm{Mg}^{2+}$. Every template was applied in duplicate and a negative control was supplied by sterilized distillated water. Reaction conditions consisted of an initial heating at $95^{\circ} \mathrm{C}$ for $4 \mathrm{~min}, 39$ cycles at $94^{\circ} \mathrm{C}$ for $15 \mathrm{~s}, 55^{\circ} \mathrm{C}$ for $20 \mathrm{~s}$ and $72^{\circ} \mathrm{C}$ for $20 \mathrm{~s}$, followed by a final elongation step at $72^{\circ} \mathrm{C}$ for $5 \mathrm{~min}$. Biotinylated PCR product were immobilized on streptavidin sepharose beads (PyroMark Binding Buffer, Qiagen), cleaned up with ethanol (70\%), denatured with sodium hydroxid $(0.2 \mathrm{M})$ and finally washed in tris-acetate $(10 \mathrm{mM})$ implementing the Vacuum Prep Worktable (Qiagen), following the instructions of the manufacturer.

Then, immobilized single strand samples were transferred to annealing buffer (Pyro Mark Annealing Buffer, Qiagen) amended with the appropriate sequencing primer, as listed in Supplementary Table 2. The samples were heated at $80^{\circ} \mathrm{C}$ for $3 \mathrm{~min}$ and then cooled to room temperature. After cooling, the samples were pyrosequenced using Pyro Mark Gold Q96 reagents (Qiagen) on a PSQ96MA machine (Qiagen), as described by the manufacturers. Samples with $100 \%$ wild-type and/or mutated isolate were used as references.

In vitro fungicides sensitivity test. The sensitivities of 45 isolates of P. teres (34 Ptt and $11 \mathrm{Ptm}$ ) from several regions in Algeria (Supplementary Table 3) were tested in microtiter tests against a range of fungicides. Sensitive and resistant isolates sampled from Europe were used as con- trol (Supplementary Table 4).

Fungicide activity of propiconazole (Tilt, Syngenta, Basel, Switzerland), tebuconazole (Folicur, Bayer, Leverkusen, Germany), epoxiconazole (Opus, BASF SE, Ludwigshafen, Germany), azoxystrobin (Amistar, Syngenta), pyraclostrobin (Cabrio, BASF SE), and fluxapyroxad (Imtrex, BASF SE), were tested (Table 1). Sensitivity tests were conducted as described for $P$. teres on the web page of the Fungicide Resistance Action Committee (FRAC) monitoring method (2019) (http://www.frac.info/monitoring-methods).

For conidial production, isolates were cultivated on POA plates $(50 \mathrm{~g}$ peanut leaf extract, $15 \mathrm{~g}$ oatmeal, $20 \mathrm{~g}$ agar and fill up to $1,000 \mathrm{ml}$ with water), and incubated under $12 \mathrm{~h}$ darkness at $18^{\circ} \mathrm{C}$, then under $12 \mathrm{~h}$ light at $22^{\circ} \mathrm{C}$ for 12 days (Speakman and Pommer, 1986). Conidia were dislodged from the surface of the plates with a Drigalski spatula, the suspension was then filtered through a single layer of cheese cloth and adjusted to a density of $4 \times 10^{3}$ spore $/ \mathrm{ml}$. Spore suspensions for each isolate were prepared in double-concentrated YBA medium (20 g of yeast extract, $20 \mathrm{~g}$ of Bacto peptone, $40 \mathrm{~g}$ of sodium acetate, filled up to $1,000 \mathrm{ml}$ with water). The formulated products of the fungicides tested, were suspended in sterile deionized water immediately before mixing with spore suspensions. Seven concentrations of each fungicide were used in microtiter assays: (0.03-0.1-0.3-1-3-10-30) for propiconazole and tebuconazole, (0.001-0.03-0.1-0.3-1-3-10) for epoxiconazole, (0.003-0.01-0.03-0.1-0.3-1-3) for azoxystrobin and fluxapyroxad, and (0.001-0.003-0.01-0.03-0.1-0.3) for pyraclostrobin (Table 1).

Different treatments with $P$. teres isolates and without spores (blanks) were tested in four replicates in 96-well microtiter plates by mixing $50 \mu 1$ of fungicide dilutions with $50 \mu \mathrm{l}$ of spore suspension or medium. Eight isolates from Europe, previously classified as sensitive or resistant to SDHI and QoIs, were used as controls. The isolates,

Table 1. Fungicides and concentrations used for microtiter and glasshouse tests

\begin{tabular}{lccccc}
\hline Class $^{\mathrm{a}}$ & Fungicide & Company $^{\mathrm{a}}$ & Formulation & $\begin{array}{c}\text { Concentrations (ppm) used } \\
\text { for microtiter test }\end{array}$ & $\begin{array}{c}\text { Concentrations (g a.i./ha) } \\
\text { used for glasshouse test }\end{array}$ \\
\hline DMI & Propiconazole & Syngenta & Tilt, 250 SC & $0.03-0.1-0.3-1-3-10-30$ & - \\
& Tebuconazole & Bayer & Folicur, 250 EW & $0.03-0.1-0.3-1-3-10-30$ & - \\
& Epoxiconazole & BASF & Opus, 125 SC & $0.001-0.03-0.1-0.3-1-3-10$ & $14-42-125$ \\
QoI & Azoxystrobin & Syngenta & Amistar, 250 SC & $0.003-0.01-0.03-0.1-0.3-1-3$ & $28-83-250$ \\
& Pyraclostrobin & BASF & Cabrio, 250 EC & $0.001-0.003-0.01-0.03-0.1-0.3$ & - \\
SDHI & Fluxapyroxad & BASF & Imtrex, 62.5 EC & $0.003-0.01-0.03-0.1-0.3-1-3$ & $14-42-125$ \\
\hline
\end{tabular}

DMI, demethylase inhibitor; QoI, quinone outside inhibitor; SDHI, succinate dehydrogenase inhibitor.

${ }^{a}$ According to ACTA (Association de Coordination Technique Agricole, 2017). 
their origins and corresponding mutations are listed in the Supplementary Table 4.

Plates were incubated in darkness at $18^{\circ} \mathrm{C}$ and growth was measured in a photometer (96-well reader) at $405 \mathrm{~nm}$ after five days. The values were then corrected by comparison with the blanks. The $\mathrm{EC}_{50}$ values (the concentration at which $50 \%$ of the fungus growth was inhibited) were determined by probit analysis and compared with sensitive and resistant (mutant) control isolates. The efficiencies of the different fungicides were then compared by $\mathrm{EC}_{50}$ values.

Glasshouse experiments. The sensitivity of 2 Algerian P. teres isolates (Pt142 and Pt157) to three fungicides, azoxystrobin (QoI), fluxapyroxad (SDHI) and epoxiconazole (DMI) was tested in planta in the glasshouse. Three resistant isolates (Pt1669, Pt1685, and Pt1900) with cytbF129L and/or s $d h-C$-G79R mutations and 2 wild types from Europe were used as controls (Supplementary Table 4). Different treatments were applied in a spray chamber using flat fan nozzles with a water amount of $400 \mathrm{l} / \mathrm{ha}$. Applications were made preventatively one day before inoculation at BBCH 11 stage. As barley cultivar "Astrid" was used, which was sown seven days before application. Three replicates were used, each one includes 10 plants cultivated in pot of $10 \mathrm{~cm}$ diameter, under $16 \mathrm{~h}$ photoperiod at $20^{\circ} \mathrm{C}$ in glasshouse. Fungicides were applied according to Table 1. After application, plants were placed in a growing chamber to dry overnight.

Spore suspensions were prepared in a malt and gelatin medium ( $2.5 \mathrm{~g}$ of malt, $2.5 \mathrm{~g}$ of gelatin and filled up to 1,000 $\mathrm{ml}$ with water). Suspensions of all isolates tested were ad- justed to $1-2 \times 10^{4}$ conidia/ml and a volume of $1-2 \mathrm{ml}$ was needed for each pot of 10 seedlings. The plants were inoculated with an airbrush $(0.8 \mathrm{~mm})$ to give complete coverage without run-off and then placed in a fully randomized experimental design. Subsequently, the inoculated plants were held in a humid chamber for 2 days, followed by a $16 \mathrm{~h}$ photoperiod at $20^{\circ} \mathrm{C}$ in glasshouse. Infected leaf area percentages were evaluated ten days after inoculation, and then compared to those recorded for the sensitive and resistant controls (Rehfus et al., 2016).

Data analysis. In order to classify Algerian isolates according to their sensitivity to each fungicide, a k-mean cluster test (MacQueen, 1967) was performed on $\mathrm{EC}_{50}$ mean values, using SPSS software (IBM SPSS Statistics version 23.0, IBM Corp., Armonk, NY, USA). Clusters were chosen to maximize the differences between the observations of the different clusters. Clustering quality was checked through an evaluation of coefficient of determination $\mathrm{R}^{2}$, and $F$ value $\left(F=\left(R^{2} / \mathrm{k}-1\right) /\left(\left(1-R^{2}\right) / \mathrm{n}-\mathrm{k}\right)\right)$. A good classification is assumed when $\mathrm{R}^{2}$ is close to 1 , and $\mathrm{F}$ is as high as possible (Tufféry, 2012). Otherwise, a T two-tailed test ( $P$ $<0.05$ ) was used to compare the $\mathrm{EC}_{50}$ values.

\section{Results}

Detection of QoI and SDHI resistance by pyrosequencing. Pyrosequencing assays were performed in order to detect $c y t b$ and $s d h(B-C)$ mutations. Results showed that no F129L or G137R mutations were found in the $c y t b$ gene in all tested isolates and no mutations in $s d h-B$ and $s d h-C$



Fig. 2. Sensitivity of Algerian Pyrenophora teres isolates towards the six fungicides tested based on $\mathrm{EC}_{50}$ values (mean $\pm \mathrm{SD}$ ), compared to sensitive and resistant control isolates sampled from Europe. SDHI, succinate dehydrogenase inhibitor; QoI, quinone outside inhibitor; DMI, demethylase inhibitor. 
Table 2. K-mean cluster test results, showing number of isolates and $\mathrm{EC}_{50}$ intervals of each cluster, recorded for the six fungicides tested

\begin{tabular}{|c|c|c|}
\hline Cluster & Interval & Isolate \\
\hline \multicolumn{3}{|c|}{ Azoxystrobin } \\
\hline A & $0.005-0.009$ & 2 \\
\hline $\mathrm{B}$ & $0.01-0.019$ & 20 \\
\hline $\mathrm{C}$ & $0.021-0.029$ & 18 \\
\hline $\mathrm{D}$ & 0.034 & 1 \\
\hline $\mathrm{E}$ & $0.038-0.041$ & 4 \\
\hline \multicolumn{3}{|c|}{ Pyraclostrobin } \\
\hline A & $0.002-0.0062$ & 9 \\
\hline B & $0.0065-0.01$ & 17 \\
\hline $\mathrm{C}$ & $0.011-0.014$ & 9 \\
\hline $\mathrm{D}$ & $0.015-0.018$ & 7 \\
\hline $\mathrm{E}$ & $0.023-0.026$ & 3 \\
\hline \multicolumn{3}{|c|}{ Fluxapyroxad } \\
\hline A & $0.008-0.0286$ & 16 \\
\hline B & $0.0307-0.044$ & 17 \\
\hline $\mathrm{C}$ & $0.0537-0.0696$ & 8 \\
\hline $\mathrm{D}$ & $0.076-0.098$ & 3 \\
\hline $\mathrm{E}$ & 0.41 & 1 \\
\hline \multicolumn{3}{|c|}{ Epoxiconazole } \\
\hline A & $0.0015-0.035$ & 15 \\
\hline B & $0.037-0.091$ & 13 \\
\hline $\mathrm{C}$ & $0.099-0.152$ & 9 \\
\hline $\mathrm{D}$ & $0.166-0.215$ & 5 \\
\hline $\mathrm{E}$ & $0.228-0.26$ & 3 \\
\hline \multicolumn{3}{|c|}{ Tebuconazole } \\
\hline A & $0.0256-0.098$ & 19 \\
\hline B & $0.113-0.216$ & 12 \\
\hline $\mathrm{C}$ & $0.251-0.315$ & 10 \\
\hline $\mathrm{D}$ & $0.37-0.444$ & 3 \\
\hline $\mathrm{E}$ & 1.217 & 1 \\
\hline \multicolumn{3}{|c|}{ Propiconazole } \\
\hline A & $0.0323-0.0835$ & 14 \\
\hline B & $0.086-0.149$ & 14 \\
\hline $\mathrm{C}$ & $0.155-0.227$ & 12 \\
\hline $\mathrm{D}$ & $0.249-0.307$ & 4 \\
\hline $\mathrm{E}$ & 0.43 & 1 \\
\hline
\end{tabular}

genes were detected, where the five mutations B-H277Y, C-N75S, C-G79R, C-H134R, and C-S135R had been tested.

Sensitivity of the Algerian $\boldsymbol{P}$. teres population towards QoIs, SDHI, and DMIs. It could be shown that the Algerian isolates tested were more sensitive to epoxiconazole and in particular to tebuconazole and propiconazole than all European samples, whereas the isolates from Algeria showed similar sensitivity to azoxystrobin, pyraclostrobin and fluxapyroxad as the QoI and/or SDHI sensitive European isolates. The effect of the fungicides on the growth inhibition of $P$. teres isolates in vitro was different (Fig. 2).

Statistical analysis of the $\mathrm{EC}_{50}$ values recorded for each fungicide (Supplementary Table 5), using the k-mean cluster, divided the isolates into 5 homogenous clusters with highly significant differences (Table 2).

Assessing the sensitivity of the Algerian $P$. teres population towards QoIs. Results showed that the mean $\mathrm{EC}_{50}$ of azoxystrobin for wild type isolates from Algeria was around $0.021 \mathrm{mg} / \mathrm{l}$ and that the $\mathrm{EC}_{50}$ values of all isolates ranged from 0.005 to $0.041 \mathrm{mg} / 1$ compared to the range of 0.39 to $1.34 \mathrm{mg} / 1$ for F129L isolates from Europe. $\mathrm{EC}_{50}$ values for pyraclostrobin of Algerian isolates ranged between 0.002 and $0.026 \mathrm{mg} / 1$ with a mean of $0.011 \mathrm{mg} / 1$. These values were also lower than for the F129L isolates $\left(\mathrm{EC}_{50}\right.$ values ranged from 0.043 to $\left.0.095 \mathrm{mg} / \mathrm{l}\right)$. The wild type and F129L differences were lower for pyraclostrobin than for azoxystrobin (Fig. 2).

According to the k-mean cluster test, about 89\% (40 isolates) of Algerian isolates had an $\mathrm{EC}_{50}$ equal or less than $0.029 \mathrm{mg} / \mathrm{l}$ for azoxystrobin, and that $93 \%$ (42 isolates) expressed an $\mathrm{EC}_{50}$ equal or less than $0.018 \mathrm{mg} / 1$ for pyraclostrobin (Table 2).

A comparison of $\mathrm{EC}_{50}$ of azoxystrobin and pyraclostrobin (baseline) for Ptt and Ptm isolates showed that the mean $\mathrm{EC}_{50}$ of the net form was equal to $0.24 \mathrm{mg} / \mathrm{l}$ and 0.11 $\mathrm{mg} / \mathrm{l}$, respectively and of the spot form about $0.21 \mathrm{mg} / \mathrm{l}$ azoxystrobin and $0.12 \mathrm{mg} / 1$ pyraclostrobin. A two-tailed ttest confirmed that the $\mathrm{EC}_{50}$ values obtained for each of the two forms were not significantly different at a level of 5\% $(P$ $=0.34$ for azoxystrobin and $P=0.76$ for pyraclostrobin).

Assessing the sensitivity of the Algerian $P$. teres population towards SDHI (baseline). For the SDHI fungicide tested (fluxapyroxad), we registered a mean $\mathrm{EC}_{50}$ of 0.047 $\mathrm{mg}$ fluxapyroxad/1 and $\mathrm{EC}_{50}$ values ranging from 0.008 to $0.098 \mathrm{mg} / \mathrm{l}$ for Algerian isolates. These values were close to those of sensitive controls (Fig. 2), whereas they were clearly lower than those expressed by isolates carrying $s d h$ $C$-G79R and $s d h-C$-N75S mutations, these values ranged from 0.64 to $4.93 \mathrm{mg}$ fluxapyroxad/1. However, the net form isolate Pt157 that had been collected in Ain-defla (Bni-mghenem) displayed a higher $\mathrm{EC}_{50}$ of $0.41 \mathrm{mg}$ fluxapyroxad/1, compared with the rest of the Algerian isolates and sensitive controls.

The statistical analysis showed that the $\mathrm{EC}_{50}$ values for the 45 Algerian isolates can also grouped in five homoge- 
neous clusters, with highly significant differences (Table 2). According to these clustering results, about 91\% (41 isolates) of $P$. teres population had an $\mathrm{EC}_{50} \leq 0.07 \mathrm{mg}$ fluxapyroxad $/ 1$ and $97.8 \%$ (44 isolates) had an $\mathrm{EC}_{50} \leq 0.098 \mathrm{mg}$ fluxapyroxad/l (Table 2). In the case of fluxapyroxad, the mean $\mathrm{EC}_{50}$ for the $P t t$ isolates was equal to $0.44 \mathrm{mg} / 1$ and to $0.22 \mathrm{mg} / \mathrm{l}$ for the $\mathrm{Ptm}$ isolates. A two-tailed t-test analysis conducted at a level of 5\% significance, confirmed that the $\mathrm{EC}_{50}$ values obtained for each form was highly significant different $(P<0.001)$.

Assessing the sensitivity of the Algerian $P$. teres population towards DMIs. In the case of DMIs, the P. teres Algerian population showed wide ranges of $\mathrm{EC}_{50}$ for the three fungicides tested. Our result showed a range of $\mathrm{EC}_{50}$ between 0.032 and $0.43 \mathrm{mg} / \mathrm{l}$ for propiconazole, 0.026 and $1.22 \mathrm{mg} / \mathrm{l}$ for tebuconazole and 0.0015 and $0.26 \mathrm{mg} / 1$ for epoxiconazole, with mean values of $0.14,0.18$, and 0.08 $\mathrm{mg} / \mathrm{l}$, respectively. Hence, Algerian population was more sensitive than DMI shifted controls, for which higher $\mathrm{EC}_{50}$ values were clearly monitored, with a mean value of 3.56 $\mathrm{mg}$ propiconazole $/ 1,15.13 \mathrm{mg}$ tebuconazole $/ \mathrm{l}$ and $0.69 \mathrm{mg}$ epoxiconazole/l.

When treated with epoxiconazole, the $\mathrm{EC}_{50}$ mean value noted for the Algerian population was very close to that of the sensitive controls. Whereas with tebuconazole and propiconazole, a clear difference in $\mathrm{EC}_{50}$ mean values was measured (Fig. 2). The k-mean cluster test indicated that the $\mathrm{EC}_{50}$ values of all tested isolates can be grouped in five clusters that display highly significant differences (Table 2 ). According to these results, about $82 \%$ (37 isolates) of the Algerian population had an $\mathrm{EC}_{50} \leq 0.152 \mathrm{mg}$ epoxicon-

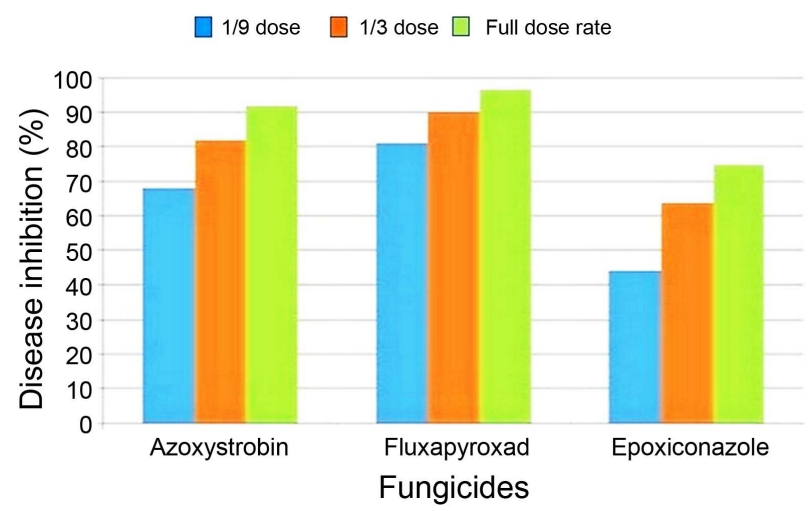

Fig. 3. Disease control efficacy (mean) of three doses (full dose, $1 / 3,1 / 9$ ) of azoxystrobin, fluxapyroxad and epoxiconazole, tested as one day preventive, against barley net blotch caused by Algerian Pyrenophora teres isolates (Pt157 and Pt142) under glasshouse conditions.

azole/1, 91\% (41 isolates) expressed an $\mathrm{EC}_{50}$ equal to or less than $0.315 \mathrm{mg}$ tebuconazole $/ 1$ and that $89 \%$ (40 isolates) indicated an $\mathrm{EC}_{50} \leq 0.227 \mathrm{mg}$ propiconazole/l(Table 2).

All DMIs tested in this investigation were more efficient against $P t t$ isolates, than Ptm isolates; this difference was significant for epoxiconazole and tebuconazole in the twotailed t-test results $(P<0.001$ and $P=0.003$, respectively). A mean $\mathrm{EC}_{50}$ of $0.07 \mathrm{mg} / \mathrm{l}$ epoxiconazole was recorded for the net blotch form, whereas a remarkably higher value of $0.15 \mathrm{mg} / \mathrm{l}$ was noted for the spot blotch form. The values recorded for $\mathrm{Ptt}$ were also less than those for Ptm isolates for tebuconazole $(0.14 \mathrm{mg} / 1$ and $0.33 \mathrm{mg} / \mathrm{l}$, respectively). However, with propiconazole, the mean $\mathrm{EC}_{50}$ of the two forms were very close with a mean $\mathrm{EC}_{50}$ of 0.13

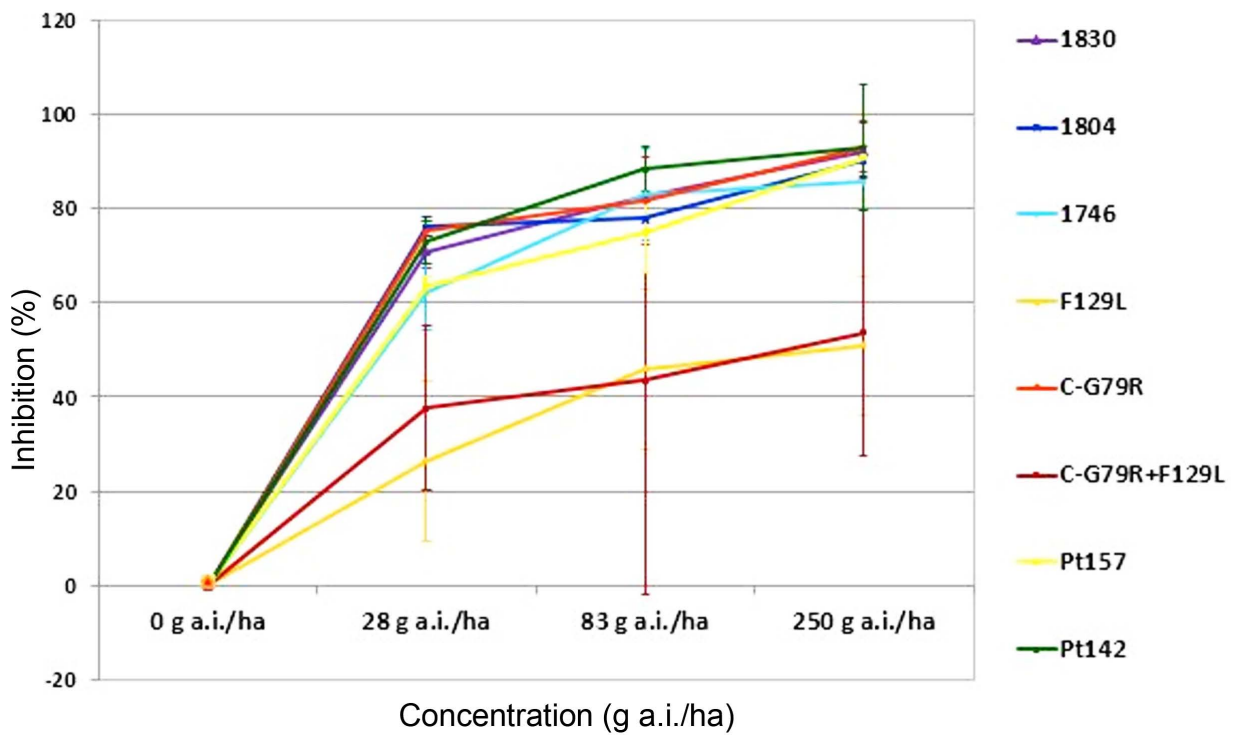

Fig. 4. Disease control efficacy (mean $\pm \mathrm{SD}$ ) of azoxystrobin in a one-day preventive treatment against barley net blotch caused by Pyrenophora teres wild-type isolates from Algeria (Pt157 and Pt142) and from Europe (Pt1830, Pt1804 and Pt1746), and by $P$. teres F129L-mutated isolates (Pt1669, Pt1685) from Europe under glasshouse conditions. 


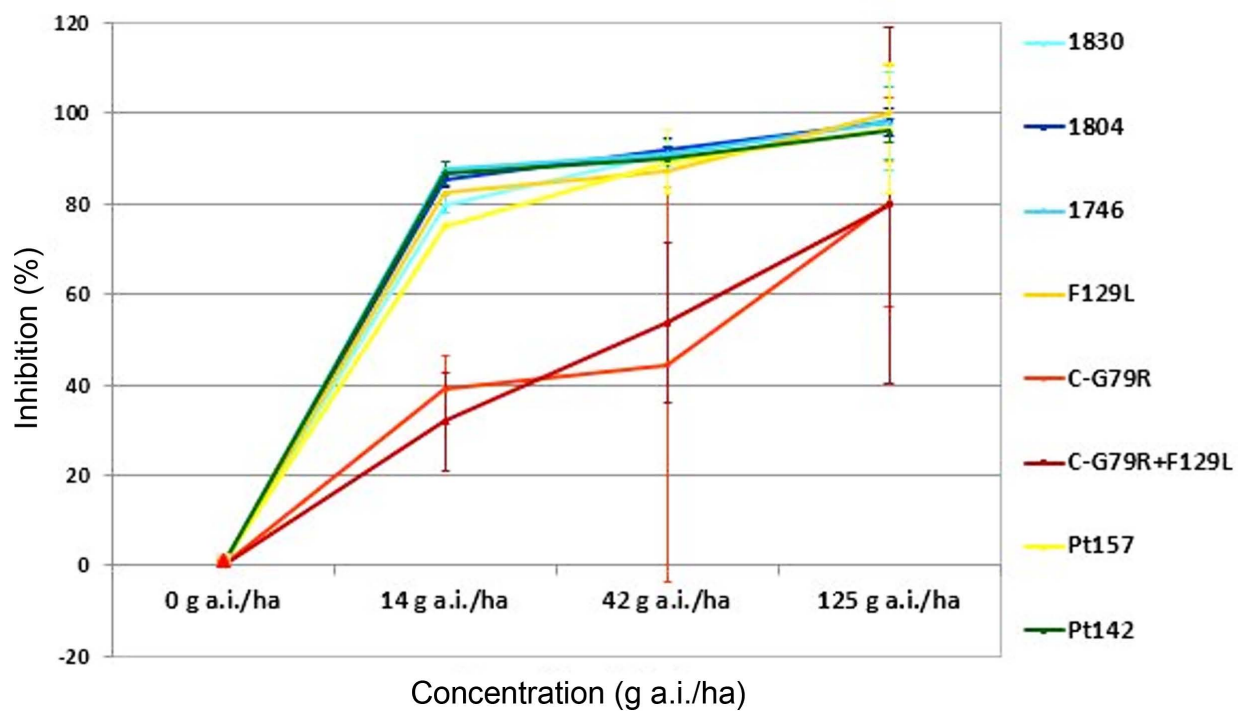

Fig. 5. Disease control efficacy (mean \pm SD) of fluxapyroxad in a one-day preventive treatment against barley net blotch caused by Pyrenophora teres wild-type isolates from Algeria (Pt157 and Pt142) and from Europe (Pt1830, Pt1804 and Pt1746), and by P. teres C-G79R mutated isolates (Pt1900 and Pt1669) from Europe under glasshouse conditions. $\mathrm{mg} / \mathrm{l}$ for $P t t$ isolates and $0.16 \mathrm{mg} / \mathrm{l}$ for $P t m$ isolates.

Glasshouse experiments (in planta). Glasshouse experiments revealed that treatments' efficacies varied between the different fungicides classes applied. Excellent growth inhibition of the Algerian isolates were obtained with azoxystrobin and fluxapyroxad treatments. Epoxiconazole showed a lower level of control of Algerian net blotch isolates, compared with other treatments. This is true for inhibition of the recommended field dose, as well as for reduced doses (Fig. 3).

Efficiencies of azoxystrobin and fluxapyroxad were affected by the $c y t b-\mathrm{F} 129 \mathrm{~L}$ and $\mathrm{s} d h-C-\mathrm{G} 79 \mathrm{R}$ mutations, respectively. This was shown with isolates Pt1685 and Pt1669 with the F129L mutation (Fig. 4) and with Pt1900 with the C-G79R mutation (Fig. 5). In the case of azoxys- trobin and fluxapyroxad, a high disease inhibition percentage was recorded, for all sensitive isolates, even at $1 / 3$ and $1 / 9$ full recommended field doses.

The curves show high control of Algerian isolates Pt157 and Pt142 with fluxapyroxad, with mean inhibition values of $81 \%, 90 \%$, and $96 \%$, respectively for $1 / 9,1 / 3$, and full dose. These values are comparable with sensitive European isolates. Pt157 was slightly less sensitive at 1/9 rate. Mean efficacy values for azoxystrobin for Algerian isolates were $68 \%, 82 \%$, and $92 \%$ for $1 / 9,1 / 3$, and full dose, respectively, and these were also similar to those of the sensitive European isolates. Also here, Pt157 was slightly less sensitive when compared to the other sensitive isolates.

In addition to this, the glasshouse tests revealed that Pt142 and Pt157 are more sensitive against epoxiconazole than European sensitive isolates. However, Pt142 was more

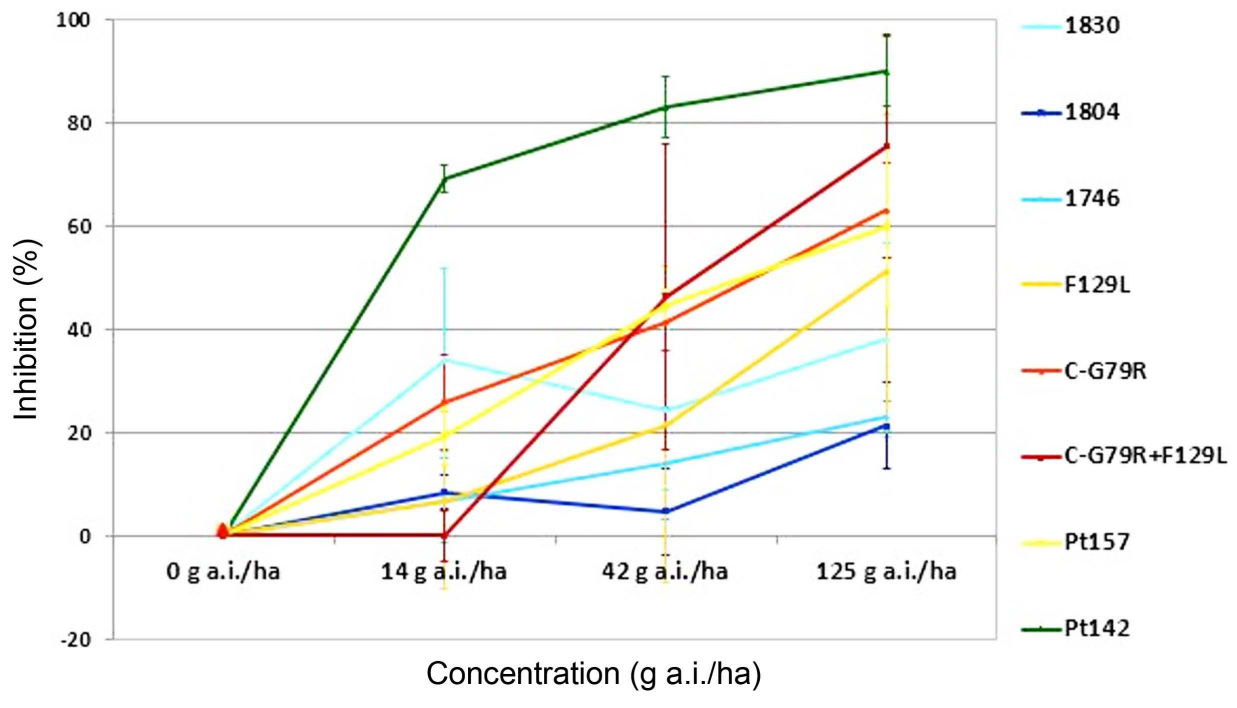

Fig. 6. Disease control efficacy (mean $\pm \mathrm{SD}$ ) of epoxiconazole in a one-day preventive treatment against barley net blotch caused by Pyrenophora teres isolates from Algeria (Pt157 and Pt142) and from Europe (Pt1830, Pt1804, Pt1746, and Pt1635) under glasshouse conditions. 
sensitive than Pt157: Inhibition rates for the isolate Pt157 were $20 \%, 44 \%$, and $60 \%$ respectively for $1 / 9,1 / 3$ and full dose of epoxiconazole and $69 \%, 83 \%$, and $90 \%$ for isolate Pt142 (Fig. 6).

\section{Discussion}

Sensitivity to QoI fungicides. Resistance to QoI fungicides in $P$. teres is conferred in nearly all cases by the F129L mutation. Single reports exist that indicate the G137R mutation also to confer QoI resistance, but this mutation is very seldom (Fungicide Resistance Action Committee, 2019). In BASF internal monitoring studies, which have also been reported to the annual FRAC meetings, the F129L was the only mutation detected in the last years of monitoring. All isolates with a lower QoI sensitivity that have been so far monitored in Europe since the launch of QoI products more than 20 years carry the F129L mutation and only rarely G137R. The G143A mutation has not been found, an intron directly after codon 143 (Grasso et al., 2006) is obviously highly conserved in both $P$. teres forms. The genetic analysis of F129L and G137R is therefore a valid method to monitor the sensitivity of populations or isolates to QoI fungicides. The data in this study indicate that there is no QoI resistance in Algeria, based on the collection of samples analysed. This is confirmed by the sensitivity analysis in our microtiter tests, which show $\mathrm{EC}_{50}$ values in a sensitive range for azoxystrobin and pyraclostrobin. The $\mathrm{EC}_{50}$ mean values for azoxystrobin and pyraclostrobin obtained for $P t t$ and for Ptm were very similar, and this is consistent with Akhavan (2017), who has assessed efficiency of pyraclostrobin against a population of Ptt and Ptm from Western Canada.

Additionally, glasshouse tests confirmed that the Algerian isolates included in these tests were as equally well controlled as the sensitive European isolates, whereas F129L isolates were less well controlled.

Sensitivity to SDHI fungicides. The resistance mechanisms for SDHI fungicides are more complex, since several mutations have been detected. These mutations cause sensitivity losses at different levels in P. teres (Fungicide Resistance Action Committee, 2019; Rehfus et al., 2016). Therefore, it is recommended to analyse the sensitivity of isolates to SDHIs stepwise. Should isolates be detected with $\mathrm{EC}_{50}$ values outside the baseline sensitivity, the target genes should be sequenced to identify the resistance mechanisms. In all cases of SDHI resistance in $P$. teres known to the authors (where internal BASF monitoring studies over many years are the most important source), mutations in the target genes $s d h-b, s d h-c$, and $s d h-d$ are the responsible resistance mechanisms. In this study, we analysed the sensitivity of 45 isolates. All were in a sensitive range, only one isolate had a slightly higher $\mathrm{EC}_{50}$ value. However, since SDHIs have still not been introduced in barley cultivation in Algeria, the presence of acquired SDHI resistance in P. teres is rather unlikely and would be against experiences in fungicide resistance monitoring studies. There is one exception known from Zymoseptoria tritici, where a case of natural, inherent resistance in around $25 \%$ of isolates of $Z$. tritici $i$ to the SHA-SDHIs fluopyram and isofetamid has been described (Steinhauer et al., 2019; Yamashita and Fraaije, 2018). This resistance is due to a paralog $s d h-c$ gene with a different amino acid sequence compared to the "normal" sdh-c gene (Steinhauer et al., 2019). Such natural resistance has not so far been identified in P. teres in the European population, despite very intensive monitoring studies.

We made an additional analysis of all isolates for five SDH-mutations known to confer SDHI resistance, including the B-H277Y, which was the first mutation detected in SDHI resistant isolates in Europe in 2012 and the C-G79R, which has been the most frequent one in SDHI resistant isolates in European populations from 2013 on. We are aware that the absence of these five mutations provide does not a fully prove for the absence of SDHI resistance, as there are some additional mutations in the $s d h-d$ gene known as resistance mechanisms (Rehfus et al., 2016), which have not been included in our study. Nevertheless, the fact that there were no isolates found with high $\mathrm{EC}_{50}$ values in addition to the absence of the in Europe earliest (B-H277R) and most frequent (C-G79R) mutations, together with the up to now absence of SDHIs in barley disease control programmes in Algeria makes it most likely that the current Algerian $P$. teres population is highly SDHI sensitive.

In case of fluxapyroxad, $\mathrm{EC}_{50}$ values differed between $P t t$ and Ptm, with a higher sensitivity of the spot form. That these differences could be caused by variations in the $s d h$ genes is rather unlikely. Sequences of the $s d h-b, s d h-c$, and $s d h-d$ sequences were obtained for 2 Ptt (from Hungary) and 4 Ptm (from different European countries) isolates by the method described by Rehfus et al. (2016) and are provided as Supplementary Figs. 1-3. The sequences are identical within the net blotch form and nearly identical between the two forms. The Ptt amino-acid sequences are identical to the sequences provided by Mair et al. (2016b). There are 5 silent single nucleotide polymorphisms (SNPs) in the $s d h-b$ gene between Ptt and Ptm. Four SNPs were found in the $s d h-c$ gene, one leads to the amino acid R46 in Ptt and K46 in Ptm. This SNP was also detected in 2013 
monitoring studies and first misinterpreted as a C-R46K mutation, which would be related to SDHI resistance (Fungicide Resistance Action Committee, 2019). Additional studies have shown that there is no link to SDHI sensitivity. The sequencing of many further isolates showed that this amino acid variation is linked to spot and net form and might serve as a valid identification tool to distinguish the two forms (data not shown). This is also true at least for the silent SNPs in the $s d h$ - $b$ gene at positions 819 and 822 , where data from a lot more isolates than the 6 shown in Supplementary Fig. 1 are available. 819 and 822 are close to the $\mathrm{H} 277$ codon, which is the target of pyrosequencing assays for the B-H277Y monitoring assay and sequence data on these positions are therefore available (data not shown). SNPs have also been detected in the $s d h-d$ gene, one of them is silent, one leads to L40 or V40, but this is not form-specific. The slight differences in the SDHsensitivity between the two forms might therefore also be caused by factors other than the $s d h$-subunits, e.g., by differences in uptake or efflux or metabolization.

The glasshouse tests showed that the Algerian isolates, including the one with the somewhat higher $\mathrm{EC}_{50}$ value in the microtiter test, were similarly well controlled as the sensitive European isolates, while the SDHI-resistant reference isolates with the C-G79R mutation were not completely controlled, even at the highest dose.

Sensitivity to DMI fungicides. The Algerian population showed a range of sensitivity to all three DMIs included, which could be the result of DMI use for several years in barley and the fact of "shifting" to lower sensitivities, as has been described by FRAC for many fungal species (Fungicide Resistance Action Committee, 2019). However, the $\mathrm{EC}_{50}$ values were lower than for European isolates, which would indicate a less adapted situation for the Algerian P. teres population. Mutations in other cereal pathogens such as Z. tritici (Huf et al., 2018) or Ramularia collo-cygni (Rehfus et al., 2019) have been found to influence DMI sensitivity. However, there are only limited data on target site mutations which influence DMI sensitivity in P. teres (Mair et al., 2016a) available. Therefore, a genetic analysis was not undertaken. All DMIs tested were more efficient against $P t t$ than against $P t m$, with a high statistical significance in case of epoxiconazole and tebuconazole. These results are in line with those of Campbell and Crous (2002), who reported that spot-form isolates from South Africa showed a lower sensitivity than net-form isolates, against five fungicides tested, these included propiconazole and tebuconazole. A tendency to a lower propiconazole sensitivity of Ptm has also been described by Akhavan
(2017) in his study with isolates from Western Canada.

The glasshouse experiments with epoxiconazole showed that some European isolates had high adaption levels, whereas the two Algerian isolates included were better controlled at the different rates. This also confirms the more advanced DMI sensitivity shift in Europe, which is most likely the result of the more intensive barley production, the higher disease pressure and, therefore, the more intensive fungicide use in many European regions.

Disease and resistance-management. SDHIs are not yet registered in Algeria, which means that the Algerian isolates had never been exposed to them. The sensitivity values can therefore been seen as representing the natural sensitivity, the baseline towards these fungicides. Knowledge of baseline sensitivity levels in unexposed pathogen populations is essential to identify early changes in sensitivity aftermarket launch of products (Russell, 2002). Early measures can then be taken in form of timely adjustment of spray programmes and other management strategies to avoid loss of field efficacy (Avenot and Michailides, 2010). The DMIs propiconazole, tebuconazole and epoxiconazole, and the QoI azoxystrobin are commonly used in Algeria for control of cereal leaf diseases that include net blotch of barley. Our study indicates a slight shift for DMIs and full sensitivity to QoIs. Therefore, DMIs and QoIs are still valuable tools in control of both forms of $P$. teres.

Based on the sensitivity values determined by the microtiter tests it could be concluded that the QoIs pyraclostrobin and azoxystrobin are most active, followed by fluxapyroxad and the DMIs. However, in planta test showed that fluxapyroxad was most efficient and provided best disease control against all wild type isolates, even at $1 / 9$ and $1 / 3$ doses. These differences between microtiter tests and glasshouse studies could be related to host effects, to the plant-pathogen interactions, retention, uptake and metabolization of the fungicide on and in the plant. Glasshouse tests are a step closer to the field and do, therefore, better reflect the efficacy of fungicide products under field conditions and are also valuable to estimate the practical relevance of acquired resistance on product performance.

Reports on fungicide sensitivity of cereal pathogens in Algeria are rare. In fact, sensitivity studies on cereal pathogens have only been reported for $Z$. tritici (Allioui et al. 2016; Meamiche Neddaf et al. 2017). They detected QoI resistance in a low percentage of isolates in various provinces of Algeria. However, considering the European experience of development and spread of QoI resistance, it is recommended to continue this research. Such results show the need for monitoring studies on fungicide sensi- 
tivity also of other cereal pathogens in Algeria for a better understanding of the current situation and an optimization of disease control and resistance management. Our study contributes insights into the situation of the sensitivity of $P$. teres to the most important fungicide classes used for net blotch control. Even if the sensitivity situation in P. teres for QoIs, SDHIs, and DMIs is, according to our investigations, quite favourable, sound resistance management strategies are mandatory to maintain the high field efficacy of these modes of action.

The objective of anti-resistance management strategies is the reduction of selection pressure to avoid or delay the occurrence of resistance, or to keep the frequency of resistant isolates in a population low. This includes continuous sensitivity monitoring and the implementation of good agricultural practice, which leads to less infection pressure (e.g., phytosanitary measurements, crop rotation, appropriate fertilization, cultivation of less susceptible varieties, appropriate crop cultivation unfavourable for both forms of $P$. teres). Limiting the number of sprays is also an important factor in delaying the build-up of resistant pathogen populations (Hobbelen et al., 2013). A further tool is the use of fungicide mixtures. Recent studies have shown that especially mixtures help to delay the selection of resistance (Hobbelen et al. 2011, 2013, 2014, Van den Bosch et al. 2014). Alternation with different modes of action is also seen as effective resistance management (Hobbelen et al., 2013). Since population size of pathogens is lower at disease onset than when already established in the field, selection pressure is less when using preventive applications rather than curative or eradicative spray schemes. An optimal timing is also an effective resistance management (Van den Berg et al., 2013). Therefore, products should be applied in a preventive manner or at early stages of disease according to the recommendations on the label and the recommendations of integrated pest management. The FRAC recommendations for the use of QoI, SDHI, and DMI in cereals are the result of many years' experience of sensitivity monitoring studies and use of these modes of action in many regions worldwide (Fungicide Resistance Action Committee, 2019). These should be considered in the advice for the use of QoIs, SDHIs, and DMIs in the control of net blotch in barley for a sustainable use in Algeria.

Conclusion. This study provides information about the current fungicide sensitivity status of the Algerian net blotch population to QoIs, SDHIs, and DMIs. To our knowledge, this is the first molecular genetic study on $c y t b$ and $s d h(B$ $C$ ) point mutations that confer $\mathrm{QoI}$ and SDHI resistance to barley net blotch in Algeria, as well as being the first evalu- ation of the sensitivity of Algerian P. teres isolates towards the six fungicides azoxystrobin, pyraclostrobin, fluxapyroxad, epoxiconazole, tebuconazole and propiconazole. Monitoring of fungicide sensitivity should be performed routinely to identify sensitivity changes at an early stage and to respond with appropriate resistance management strategies.

\section{Acknowledgments}

We thank Dr. John Speakman for critical review of the manuscript. As well as we express our grateful to (i) Angelika Hawlik, Birgit Wieja and Gabriele Berthold for their excellent technical assistance, (ii) The General Direction of Agricultural Services, departments of Boumedès and Bouira, Algeria and (iii) The National Institute of Agronomic Research (INRAA), Bejaia, Algeria, for their precious technical and logistic assistance during the survey.

\section{Electronic Supplementary Material}

Supplementary materials are available at The Plant Pathology Journal website (http://www.ppjonline.org/).

\section{References}

Akhavan, A. 2017. Genetic structure, virulence and fungicide sensitivity of Pyrenophora teres f. teres and P. teres f. maculata populations from western Canada. Ph.D. thesis. University of Alberta, Alberta, Canada.

Allioui, N., Siah, A., Brinis, L., Reignault, P. and Halama, P. 2016. Identification of Qol fungicide-resistant genotypes of the wheat pathogen Zymoseptoria tritici in Algeria. Phytopathol. Mediterr. 55:89-97.

Angelini, R. M. D. M., Pollastro, S. and Faretra, F. 2015. Genetics of fungicide resistance. In: Fungicide resistance in plant pathogens: principles and a guide to practical management, eds. by H. Ishii and D. W. Hollomon, pp. 13-34. Springer Japan, Tokyo, Japan.

Association de Coordination Technique Agricole. 2017. Index phytosanitaire. Association de Coordination Technique Agricole, Paris, France. 1060 pp.

Avenot, H. F. and Michailides, T. J. 2010. Progress in understanding molecular mechanisms and evolution of resistance to succinate dehydrogenase inhibiting (SDHI) fungicides in phytopathogenic fungi. Crop Prot. 29:643-651.

Benbelkacem, A. 1996. Adaptation of cereal cultivars to extreme agroecologic environments of North Africa. Field Crops Res. 45:49-55.

Benbelkacem, A., Benslimane, H., Arkoub, F. Z., Zouaoui, B., Boulif, M. and Aissat, A. 2002. Net blotch and leaf stripe of barley in Algeria: incidence of pathogens, pathological diver- 
sity and resistance to Pyrenophora graminea and P. teres. In: Proceeding of the 2nd Symposium of Barley Foliar Diseases, eds. by A. H. Yahyaoui, L. Brader, A. Tekauz, H. Wallwork and B. Steffenson. ICARDA, Aleppo, Syria.

Boungab, K., Belabid, L., Fortas, Z. and Bayaa, B. 2012. Pathotype diversity among Algerian isolates of Pyrenophora teres $\mathrm{f}$. teres. Phytopathol. Mediterr. 51:577-586.

Brent, K. J. and Hollomon, D. W. 2007. Fungicide resistance: the assessment of the risk. 2nd ed. Fungicide Resistance Action Committee, Brussels, Belgium. 53 pp.

Campbell, G. F. and Crous, P. W. 2002. Fungicide sensitivity of South African net- and spot-type isolates of Pyrenophora teres to ergosterol biosynthesis inhibitors. Australas. Plant Pathol. 31:151-155.

Direction de la Protection des Végétaux et des Contrôles Techniques (DPVCT). 2017. Index des produits phytosanitaires à usage agricole. DPVCT, Algiers, Algeria. 230 pp. (in French).

Fernández-Ortuño, D., Torés, J. A., de Vicente, A. and PérezGarcía, A. 2008. Mechanisms of resistance to QoI fungicides in phytopathogenic fungi. Int. Microbiol. 11:1-9.

Fisher, N. and Meunier, B. 2008. Molecular basis of resistance to cytochrome bc1 inhibitors. FEMS Yeast Res. 8:183-192.

Food and Agriculture Organization of the United Nations. 2020. FAOSTAT. http://www.fao.org/faostat/en/\#data/QC [23 April 2020].

Fungicide Resistance Action Committee. 2019. QoI working group of FRAC, Minutes of the meeting All crops: December 11th, 2013 Organised by Syngenta in Frankfurt, Germany. URL http://www.frac.info/ [23 April 2020].

Ghalem-Djender, Z., Boukhobza, N., Yallaoui-Yaici, N., Meziani, M., Oumedjkane, K., Mahiddine, D., Ait Ghezali, A., Chaou, L., Kaced, K. and Bouziri, S. 2016. Répartition des variétés de céréales à paille au niveau des zones-écologiques du nord de l'Algérie et choix variétal [Distribution of straw cereal varieties in the ecological zones of northern Algeria and variety choice]. Céréaliculture 67:43-69 (in French).

Grasso, V., Palermo, S., Sierotzki, H., Garibaldi, A. and Gisi, U. 2006. Cytochrome b gene structure and consequences for resistance to Qo inhibitor fungicides in plant pathogens. Pest Manag. Sci. 62:465-472.

Hales, N. 2015. Algeria: grain and feed annual. URL https://apps. fas.usda.gov/newgainapi/api/report/downloadreportbyfilena me?filename $=$ Grain $\% 20$ and $\% 20$ Feed $\% 20$ Annual_Algiers Algeria_4-1-2015.pdf [23 April 2020].

Hobbelen, P. H., Paveley, N. D., Oliver, R. P. and van den Bosch, F. 2013. The usefulness of fungicide mixtures and alternation for delaying the selection for resistance in populations of Mycosphaerella graminicola on winter wheat: a modeling analysis. Phytopathology 103:690-707.

Hobbelen, P. H. F., Paveley, N. D. and van den Bosch, F. 2011. Delaying selection for fungicide insensitivity by mixing fungicides at a low and high risk of resistance development: a modeling analysis. Phytopathology 101:1224-1233.

Hobbelen, P. H. F., Paveley, N. D. and van den Bosch, F. 2014.
The emergence of resistance to fungicides. PLOS ONE 9:e91910.

Huf, A., Rehfus, A., Lorenz, K. H., Bryson, R., Vögele, R. T. and Stammler, G. 2018. Proposal for a new nomenclature for CYP51 haplotypes in Zymoseptoria tritici and analysis of their distribution in Europe. Plant Pathol. 67:1706-1712.

Lamb, D., Kelly, D. and Kelly, S. 1991. Molecular aspects of azole antifungal action and resistance. Drug Resist. Updat. 2:390-402.

Lammari, H.-I., Rehfus, A., Stammler, G., Fellahi, Z. E. A., Benbelkacem, A. and Benslimane, H. 2020. Occurrence and frequency of spot form and net form of net blotch disease of barley in Algeria. J. Plant Dis. Prot. 127:35-42.

Liu, Z., Ellwood, S. R., Oliver, R. P. and Friesen, T. L. 2011. Pyrenophora teres: profile of an increasingly damaging barley pathogen. Mol. Plant Pathol. 12:1-19.

López-Ruiz, F. J., Pérez-García, A., Fernández-Ortuño, D., Romero, D., García, E., de Vicente, A., Brown, J. K. M. and Torés, J. A. 2010. Sensitivities to DMI fungicides in populations of Podosphaera fusca in south central Spain. Pest Manag. Sci. 66:801-808.

MacQueen, J. 1967. Some methods for classification and analysis of multivariate observations. In: Proceedings of the 5th Berkeley Symposium on Mathematical Statistics and Probability, eds. by L. Le Cam and J. Neyman, pp. 281-297. University of California Press, Berkeley, CA, USA.

Mair, W. J., Deng, W., Mullins, J. G. L., West, S., Wang, P., Besharat, N., Ellwood, S. R., Oliver, R. P. and Lopez-Ruiz, F. J. 2016a. Demethylase inhibitor fungicide resistance in Pyrenophora teres $\mathrm{f}$. sp. teres associated with target site modification and inducible overexpression of Cyp51. Front. Microbiol. 7:1279.

Mair, W., Lopez-Ruiz, F., Stammler, G., Clark, W., Burnett, F., Hollomon, D., Ishii, H., Thind, T. S., Brown, J. K. M., Fraaije, B., Cools, H., Shaw, M., Fillinger, S., Walker, A.-S., Mellado, E., Schnabel, G., Mehl, A. and Oliver, R. P. 2016b. Proposal, for a unified nomenclaturefor target-site mutations associated withresistance to fungicides. Pest Manag. Sci. 72:1449-1459.

Marzani, Q. A., Swarbrick, P. and Rossall, S. 2013. Correlation of the F129L mutation in Pyrenophora teres, the pathogen of net blotch of barley, with the efficacy of QoI fungicides. IOSR J. Agric. Vet. Sci. 3:66-72.

McDonald, B. A. and Linde, C. 2002. Pathogen population genetics, evolutionary potential, and durable resistance. Annu. Rev. Phytopathol. 40:349-379.

Meamiche Neddaf, H., Aouini, L., Bouznad, Z. and Kema, G. H. J. 2017. Equal distribution of mating type alleles and the presence of strobilurin resistance in Algerian Zymoseptoria tritici field populations. Plant Dis. 101:544-549.

Observatoire National des filières Agricoles et Agroalimentaires. 2019. Bilan du commerce extérieur algérien des céréales, 2018 [Algerian cereals external trade balance, 2018]. Ministère de l'Agriculture, du Développement Rural et de la Pêche, Algeria. 6 pp. (in French). 
Peltonen, S., Jalli M., Kammiovirta, K. and Karjalainen, R. 1996. Genetic variation in Drechslera teres populations as indicated by RAPD markers. Ann. Appl. Biol. 128:465-477.

Rahal-Bouziane, H. 2015. L'orge en Algérie: passé, présent et importance pour la sécurité alimentaire face, aux nouveaux défis [Barley in Algeria: past, present and importance for food security in the face of new challenges]. Rech. Agron. 27:7-24 (In French).

Reddy, P. P. 2013. Recent advances in crop protection. Springer India, New Delhi, India. 259 pp.

Reguieg, M. M., Labdi, M., Benbelkacem, A., Hamou, M., Maatougui, M. E. H., Grando, S. and Ceccarelli, S. 2013. First experience on participatory barley breeding in Algeria. J. Crop Improv. 27:469-486.

Rehfus, A. 2018. Analysis of the emerging situation of resistance to succinate dehydrogenase inhibitors in Pyrenophora teres and Zymoseptoria tritici in Europe. Ph.D. thesis. University of Hohenheim, Stuttgart, Germany.

Rehfus, A., Matusinsky, P., Strobel, D., Bryson, R. and Stammler, G. 2019. Mutations in target genes of succinate dehydrogenase inhibitors and demethylation inhibitors in Ramularia collo-cygni in Europe. J. Plant Dis. Prot. 126:447-459.

Rehfus, A., Miessner, S., Achenbach, J., Strobel, D., Bryson, R. and Stammler, G. 2016. Emergence of succinate dehydrogenase inhibitor resistance of Pyrenophora teres in Europe. Pest Manag. Sci. 72:1977-1988.

Russell, P. E. 2002. Sensitivity baselines in fungicide resistance research and management. FRAC Monograph, no. 3. Crop Life International, Brussels, Belgium. 56 pp.

Sayoud, R., Ezzahiri, B. and Bouznad, Z. 1999. Les maladies des céréales et des légumineuses alimentaires au Maghreb [Diseases of cereals and pulses in the Maghreb]. ITGC, Alger, Algeria. 64 pp. (in French).

Semar, M., Strobel, D., Koch, A., Klappach, K. and Stammler, G. 2007. Field efficacy of pyraclostrobin against populations of Pyrenophora teres containing the F129L mutation in the cytochrome $b$ gene. J. Plant Dis. Prot. 114:117-119.

Sierotzki, H., Frey, R., Wullschleger, J., Palermo, S., Karlin, S., Godwin, J. and Gisi, U. 2007. Cytochrome b gene sequence and structure of Pyrenophora teres and P. tritici-repentis and implications for QoI resistance. Pest Manag. Sci. 63:225-233.

Speakman, J. B. and Pommer, E.-H. 1986. A simple method for producing large volumes of Pyrenophora teres spore suspen- sion. Bull. Br. Mycol. Soc. 20:129-130.

Srivastava, K. D. and Tewari A. K. 2002. Fungal disease of wheat and barley: foliar diseases. In: Disease of field crops, eds. by V. K. Gupta and Y. S. Paul, pp. 58-78. Indus Publishing Company, New Delhi, India.

Steinhauer, D., Salat, M., Frey, R., Mosbach, A., Luksch, T., Balmer, D., Hansen, R., Widdison, S., Logan, G., Dietrich, R. A., Kema, G. H. J., Bieri, S., Sierotzki, H., Torriani, S. F. F. and Scalliet, G. 2019. A dispensable paralog of succinate dehydrogenase subunit $\mathrm{C}$ mediates standing resistance towards a subclass of SDHI fungicides in Zymoseptoria tritici. PLoS Pathog. 15:e1007780.

Stepanović, M., Rekanović, E., Milijašević-Marčić, S., Potočnik, I., Todorović, B. and Stepanović, J. 2016. Field efficacy of different fungicide mixtures in control of net blotch on barley. Pestic. Phytomed. 31:51-57.

Tucker, M., Lopez-Ruiz, F., Jayasena, K. and Oliver, R. 2015. Origin of fungicide-resistant barley powdery mildew in Western Australia: lessons to be learned. In: Fungicide resistance in plant pathogens: principles and a guide to practical management, eds. by H. Ishii and D. W. Hollomon, pp. 329-340. Springer Japan, Tokyo, Japan.

Tufféry, S. 2012. Data mining et statistique décisionnelle: l'intelligence des données [Data mining and decision statistics: data intelligence]. Editions Technip, Paris, France. 826 pp.

van den Berg, F., van den Bosch, F. and Paveley, N. D. 2013. Optimal fungicide application timings for disease control are also an effective anti-resistance strategy: a case study for Zymoseptoria tritici (Mycosphaerella graminicola) on wheat. Phytopathology 103:1209-1219.

Van den Bosch, F., Paveley, N., van den Berg, F., Hobbelen, P. and Oliver, R. 2014. Mixtures as a fungicide resistance management tactic. Phytopathology 104:1264-1273.

Weibull, J., Walther, U., Sato, K., Habekuß, A., Kopahnke, D. and Proeseler, G. 2003. Diversity in resistance to biotic stresses. In: Developments in plant genetics and breeding, vol. 7. Diversity in barley (Hordeum vulgare), eds. by R. von Bothmer, T. van Hintum, H. Knüpffer, and K. Sato, pp. 143-178. Elsevier Science, Amsterdam, The Netherlands.

Yamashita, M. and Fraaije, B. 2018. Non-target site SDHI resistance is present as standing genetic variation in field populations of Zymoseptoria tritici. Pest Manag. Sci. 74:672-681. 